\title{
Origin of elevational replacements in a clade of nearly flightless birds - most diversity in tropical mountains accumulates via secondary contact following allopatric speciation
}

\author{
Carlos Daniel Cadena and Laura N. Céspedes \\ Departamento de Ciencias Biológicas, Universidad de los Andes, Bogotá, Colombia \\ ccadena@uniandes.edu.co
}

\begin{abstract}
Tropical mountains are biodiversity hotspots. In particular, mountains in the Neotropics exhibit remarkable beta diversity reflecting species turnover along elevational gradients. Elevational replacements of species have been known since early surveys of the tropics, but data on how such replacements arise are scarce, limiting our understanding of mechanisms underlying patterns of diversity. We employed a phylogenetic framework to evaluate hypotheses accounting for the origin of elevational replacements in the genus Scytalopus (Rhinocryptidae), a speciose clade of passerine birds with limited dispersal abilities occurring broadly in the Neotropical montane region. We found that species of Scytalopus have relatively narrow elevational ranges, closely related species resemble each other in elevational distributions, and most species replacing each other along elevational gradients are distantly related to each other. Although we cannot reject the hypothesis that a few elevational replacements may reflect parapatric speciation along mountain slopes, we conclude that speciation in Scytalopus occurs predominantly in allopatry within elevational zones, with most elevational replacements resulting from secondary contact of formerly allopatric lineages. Our study suggests that accumulation of species diversity in montane environments reflects colonization processes as opposed to in situ divergence even in dispersal-limited animals.
\end{abstract}

\section{Introduction}

Species turnover along elevational gradients is a salient pattern in tropical biogeography. Ever since pioneering work by Francisco José de Caldas and Alexander von Humboldt on plant geography, naturalists have noticed that many species occur over narrow ranges of elevation and replace each other along mountain slopes (Nieto, 2006; von Humboldt \& Bonpland, 2009). Elevational replacements of closely related species are prevalent in the tropics (Terborgh, 1971; Diamond, 1973; Wake \& Lynch, 1976), where organisms likely have narrower physiological tolerances than in temperate zones (Janzen, 1967; McCain, 2009). Marked changes in species assemblages with elevation (e.g. of plants, invertebrates and vertebrates; Patterson et al., 1998; Kessler, 2001; Jankowski et al., 2013b; García-Robledo et al., 2016; Gill et al., 2016; Badgley et al., 2018) thus result in tropical mountains being hotspots of beta diversity (Melo et al., 2009; Fjeldså et al., 2012). Therefore, knowledge about evolutionary and ecological mechanisms involved in the origin of elevational replacements is central to understanding major patterns in the distribution of life (Janzen, 1967; Huey, 1978).

Abutting species distributions along elevational gradients may reflect either (1) parapatric ecological speciation leading to divergence of a formerly widespread species into two or more daughter species with restricted ranges, or (2) secondary contact following range expansions of species originating in allopatry (Endler, 1982; Hua, 2016). Although one should exercise caution when making inferences about the geographic context of speciation based on current geographic distributions (Losos \& Glor, 2003), these alternative hypotheses are, in principle, amenable to testing by means of phylogenetic analyses: parapatric divergence predicts that species replacing each other with elevation are sister to each other, whereas secondary contact predicts they are not (Patton \& Smith, 1992; Moritz et al., 2000). The few studies testing these predictions on animals indicate that most speciation in the montane Neotropics occurs in allopatry and that species replacing each other along elevational gradients are not each other's closest relatives (Patton \& Smith, 1992; Cadena et al., 2012; Caro et al., 2013). Therefore, elevational replacements may primarily reflect secondary contact but more studies are necessary to confirm this pattern.

As evidenced by some of the first large-scale surveys of the geographic and ecological distributions of species (Chapman, 1917; Todd \& Carriker, 1922; Chapman, 1926), most birds living in montane areas of the Neotropics have narrow 
elevational ranges (Jankowski et al., 2013a; but see Gadek et al., 2018 for exceptions). For example, median ranges of species across their geographic distributions span only ca. $1100 \mathrm{~m}$ in three families of Neotropical birds (Figure 1; see also Graves, 1988). Narrow elevational ranges of individual species are often coupled with segregation with ecologically similar species along mountain slopes. For instance, a series of landmark studies in the Peruvian Andes documented multiple cases of pairs of congeneric species of birds replacing each other with elevation as well as scenarios where up to 4-5 congeners occur successively along mountain slopes with minimum overlap (Terborgh, 1971; Terborgh \& Weske, 1975; Terborgh, 1977). Understanding ecological and physiological mechanisms maintaining patterns of elevational segregation in tropical birds has been the focus of multiple studies (reviewed by Jankowski et al., 2013a), yet analyses of the origins of elevational replacements remain scarce (Cadena, 2007; Freeman, 2015; Cadena et al., 2019a). In particular, we are unaware of studies attempting to test alternative hypotheses accounting for the origin of elevational replacements in a diverse clade of widespread organisms in the context of a robust phylogeny.

Tapaculos in the genus Scytalopus (Rhinocryptidae) are small passerine birds with poor dispersal abilities ranging broadly in the Neotropical montane region. Except for the Pantepui, species in the genus occupy all major mountains in the Neotropics from Costa Rica to Patagonia, reaching lowland areas and foothills in southern South America and eastern Brazil. Scytalopus are mouse-like birds which forage by walking or hopping on or near the ground in dense vegetation; they are unable to engage in long, powered flights because they have small and rounded wings and unfused clavicles (Figure 2; Krabbe \& Schulenberg, 2003; Maurício et al., 2008). Scytalopus avoid highly lit open areas and are rarely found far from vegetation cover except in barren high-elevation environments. Local diversity of Scytalopus is typically low, yet multiple species may be found in different habitats in a given landscape, being prime examples of patterns of elevational replacement (Krabbe \& Schulenberg, 1997, 2003). For example, on a single morning walking trails upslope in forests along the Cerro de Montezuma on the Pacific-facing slope of the Andes of Colombia, birdwatchers may successively encounter S. chocoensis, S. alvarezlopezi, S. vicinior, S. spillmanni, and S. latrans; if they visit paramos at higher elevations in the region, they may also find $S$. canus (Stiles et al., 2017; see below). Elevational replacements in the genus are typically sharp. Species seldom co-occur at the same elevations and when they do so, they often segregate by habitat. Current taxonomy recognizes 44 species of Scytalopus, but this is most certainly an underestimate given marked genetic structure within species, geographic variation in vocalizations, and the potential for discovery of new taxa in unexplored regions (Cadena et al., 2019b).

Elevational replacements in Scytalopus are somewhat paradoxical given both main hypotheses posed to account for such patterns. First, given the morphological and life-history traits making these birds poor dispersers one would expect that long-distance dispersal or range expansions would hardly bring multiple species together in a given slope, especially because mountain regions are separated by geographic barriers associated with population isolation and diversification in other birds (Hazzi et al., 2018). Alternatively, given what we know about the geographic context of speciation in birds in general (Phillimore et al., 2008; Price, 2008) and in the Andes in particular (García-Moreno \& Fjeldså, 2000; Caro et al., 2013), parapatric divergence of multiple species along elevational gradients in several geographic regions would also appear unlikely. A preliminary analysis of diversification in Scytalopus focusing on few taxa from eastern Ecuador and Peru suggested secondary contact is a more likely explanation for elevational replacements (Arctander \& Fjeldså, 1994; Roy et al., 1997). However, because the phylogeny employed for analyses may have been problematic (Arctander, 1995), taxonomic and geographic coverage were limited, and the substantial improvement of our understanding of geographic ranges, species limits, and diversity in Scytalopus (Krabbe \& Schulenberg, 1997; Cadena et al., 2019b), revisiting these questions is warranted. We used a comprehensive molecular phylogeny and data on geographic and elevational distributions of species to describe the mode of speciation and thereby examine the origin of elevational replacements in Scytalopus.

\section{Methods}

A recent study reconstructed molecular phylogenies of Scytalopus employing sequences of mitochondrial DNA (mtDNA), 80 nuclear exons, and $>1800$ regions flanking ultraconserved elements in the nuclear genome (Cadena et al., 2019b). We used the mtDNA ND2 data set from that study, which had denser taxonomic and geographic sampling, as the basis for our analyses; phylogenies inferred with this data set were largely congruent with those based on nuclear data for 
nodes relevant to analyses we present here. We inferred a gene tree using Beast 2.4 .8 (Bouckaert et al., 2014) for an alignment of 90 sequences, including 83 Scytalopus and seven outgroups. We applied a relaxed uncorrelated clock (mean=0.0125, SD=0.15; Smith \& Klicka, 2010) and a Yule speciation tree prior. We ran chains for 100 million generations and discarded the initial $50 \%$ as burn-in.

We were able to gather elevational distribution data for 57 taxa of Scytalopus; these represent all named species as well as several distinct populations, which may be undescribed species given genetic divergence, vocal variation, or geographic distributions (see Cadena et al., 2019b). We obtained information on elevational ranges from taxonomic descriptions and other papers (Whitney, 1994; Krabbe \& Schulenberg, 1997; Cuervo et al., 2005; Krabbe et al., 2005; Maurício, 2005; Bornschein et al., 2007; Donegan \& Avendaño-C., 2008; Vasconcelos et al., 2008; Krabbe \& Cadena, 2010; Whitney et al., 2010; Donegan et al., 2013; Hosner et al., 2013; Maurício et al., 2014; Avendaño et al., 2015; Avendaño \& Donegan, 2015; Stiles et al., 2017), regional handbooks (Fjeldså \& Krabbe, 1990; Ridgely \& Greenfield, 2001; Hilty, 2003; Restall et al., 2007; Schulenberg et al., 2007; Herzog et al., 2016; Ayerbe-Quiñones, 2018), and the Handbook of the Birds of the World (del Hoyo et al., 2018). Additionally, fo several taxa we defined elevational distributions based on expert knowledge (A M. Cuervo, N. K. Krabbe, D. F. Lane, T. S. Schulenberg, and V. Piacentini, unpubl. data); this was particularly useful for unnamed populations differing phenotypically or genetically from others. We performed all analyses described below using all 57 taxa and separately for a data set including only 47 of them which represent all currently recognized species (American Ornithologists' Union 1998; Stiles et al., 2017; Remsen et al., 2018) plus three unnamed species from the Andes of Peru (an unnamed form referred to S. altirostris mentioned by Cadena et al., 2019b was not considered). To conduct analyses, we trimmed the phylogeny constructed with the complete data set (i.e., 90 terminals) to include only the 57 or 47 taxa considered. The elevation ranges for species in the 47 -taxon data set encompassing more than one taxon in the 57-taxon data set correspond to the combined ranges of these taxa (e.g. the range of $S$. rodriguezi in the 47-taxon data set is $1700-2300 \mathrm{~m}$, i.e. the combined range of forms rodriguezi and yariguiorum).

To describe changes in elevational distributions over the history of Scytalopus, we mapped the midpoint of the elevation range of each taxon in the phylogeny using the contMap function of phytools, which estimates character states at nodes and along branches using a maximum-likelihood approach (Revell, 2012). Additionally, we calculated Pagel's $\lambda$ (Pagel, 1999) as a measure of phylogenetic signal of midpoint elevation and accounted for phylogenetic uncertainty by calculating this statistic across the final 1,001 trees in the posterior distribution using phytools. Using likelihood-ratio tests, we also tested whether Pagel's $\lambda$ in each tree was significantly different from 0 (i.e. no phylogenetic signal) and 1 (i.e. the value expected under pure Brownian motion). Phylogenetic signal is often interpreted in terms of the degree of conservatism or lability of a trait (e.g. Blomberg et al., 2003), but inferences about factors underlying patterns should be cautious because different evolutionary processes may produce similar values of phylogenetic signal (Revell et al., 2008). Nonetheless, high phylogenetic signal can be interpreted as a strong tendency of closely related species to resemble each other in a given trait (Revell et al., 2008). Therefore, high phylogenetic signal in elevational ranges could indicate close resemblance between close relatives in such ranges. In addition to examining the midpoint of elevational ranges of species, we also conducted analyses based on minimum and maximum elevation, obtaining qualitatively similar results.

To evaluate whether sister taxa have similar or contrasting elevational distributions as predicted by allopatric and parapatric speciation, respectively (Patton \& Smith, 1992), we identified sister taxa across the 1,001 final trees in the posterior distribution. We then calculated the elevational overlap of pairs of sister taxa by dividing the amount of overlap by the elevational range of the taxon with the narrowest range (Kozak \& Wiens, 2007; Cadena et al., 2012). A value of 1 indicates that either ranges are exactly the same or that the narrower range is entirely contained in the wider range; a value of 0 indicates that elevational distributions do not overlap. The number of pairs of sister taxa employed for analyses varied across trees in the posterior from 18 to 23 (median $=20.3$, total across trees $=51$ pairs) in the 57 tip data set, and from 12 to 18 (median $=15.1$, total across trees $=52$ pairs) in the 47-tip data set. These analyses were restricted to sister taxa representing terminal branches in the phylogeny (i.e., we did not employ ancestral state reconstructions to compare elevational ranges in cases when a species representing a long terminal branch was sister to a clade formed by $\geq 2$ species). 
Finally, we graphically examined the phylogenetic affinities of species of Scytalopus replacing each other along elevational gradients in four regions of South America to examine whether such replacements more likely reflect secondary contact or parapatric speciation along mountain slopes. These regions were: (A) the Sierra Nevada de Santa Marta in northern Colombia, (B) the Pacific slope of the Western Cordillera of Colombia, (C) Zamora-Chinchipe Province on the Amazonian slope of the Andes of Ecuador, and (D) the Río Satipo Valley in Junín Department, eastern Andean slope of Peru. All analyses were conducted and figures plotted in the R programming environment (R Core Team 2018).

\section{Results}

Scytalopus tapaculos jointly occupy a wide range of elevations in the Neotropics, from sea level up to $4,600 \mathrm{~m}$ in the high Andes (Table 1, Figure 3). Elevational ranges vary substantially among species, from very narrow (200 m) to quite broad $(3,500 \mathrm{~m})$, yet most species occupy only a relatively small fraction of the elevational gradients in which they occur: mean ranges were $1079 \mathrm{~m}(\mathrm{SD}=625 \mathrm{~m})$ in the 57 -taxa data set and $1166 \mathrm{~m}(\mathrm{SD}=641 \mathrm{~m})$ in the 47 -taxa data set. Given the geographic setting where most species of Scytalopus occur, where mountains reach very high altitudes and habitats for birds may extend over several thousand meters (e.g., Figure 1), the elevational ranges of species are generally rather narrow. Overall, taxa within main clades of Scytalopus have roughly similar elevational distributions. For example, most species in the Southern Andean clade (Figure 3, clade B) occur exclusively at high elevations; exceptions include $S$. fuscus, found in lowlands, and S. magellanicus, a temperate-zone species with the widest range in the genus (0 to 3,500 m). Species from the tropical Andes and Central America (Figure 3, clade C) show wide variation in elevational distributions, but species within subclades in the region tend to have similar ranges. For example, species in clades D, G and I all occur at high elevations in the tropical Andes except for S. femoralis, S. micropterus and S. caracae, which inhabit lower elevations than their close relatives (Figure 3). All taxa in clades $\mathrm{E}, \mathrm{F}$ and $\mathrm{H}$ occur at mid elevations, with some ranging to lower elevations (Figure 3). All species from Brazil (Figure 3, clade A) occur at low to mid elevations, an unsurprising pattern given that mountains reach much lower elevations in that region than in the Andes.

Phylogenetic signal for the midpoint of the elevational range of species measured by Pagel's $\lambda$, which differed significantly from 0 across all trees and for both data sets $(\mathrm{p}<0.001)$, was relatively high (mean=0.89 for the 57 -taxon data set and 0.86 for the 47-taxon data set; Figure 3). However, in most trees ( $77 \%$ in the 57 -taxon data set and $64 \%$ in the 47 -taxon data set) phylogenetic signal was also significantly different from $1(\mathrm{p}<0.05)$, implying that elevational ranges are more divergent than expected given evolution under pure Brownian motion. These results indicate that closely related Scytalopus tend to strongly resemble each other in the midpoint of their elevation ranges, but differences among species cannot be fully accounted for by time since their divergence. The minimum and maximum elevations in the ranges of species also had significant phylogenetic signal; estimates of Pagel's $\lambda$ for maximum elevation were very similar to those we obtained for midpoint elevation, while those for minimum elevation were slightly lower yet qualitatively similar (data not shown).

Most sister taxa in Scytalopus have similar elevational distributions (Figure 4). Mean overlap in elevational ranges between sister taxa was slightly higher in the 57-taxon data set (pooled mean across the 1,001 trees $=0.76, \mathrm{SD}=0.33$ ) than in the 47-taxon data set (mean=0.70, $\mathrm{SD}=0.38$ ). Regardless of the data set employed for analyses, half or more pairs of sister taxa overlapped substantially in elevational ranges (overlap $>0.8$ ) while less than a quarter of pairs of sister taxa had distinct elevational ranges (overlap $<0.2$; Figure 4 ). Furthermore, the majority of sister taxa identified across the 1,001 trees (10 pairs out of 11 , or 12 out of 13 depending on the data set) showing overlap $<0.2$ do not occur on the same gradient, i.e. they are allopatric. These results suggest speciation in Scytalopus occurs predominantly within elevational zones and not in parapatry along mountain slopes. The only possible exception to this pattern is divergence between $S$. acutirostris and S. femoralis, which may or may not be sister species, but are close relatives replacing each other along the Amazonian slope of the Central Andes of Peru (see below). We note that our analyses included data for at most 57 taxa yet the true number of species in Scytalopus is likely higher. Because most of the lineages which we did not consider are closely allied to other lineages with similar elevational ranges (e.g. groups within $S$. atratus or $S$. parvirostris; Cadena et al. $2019 \mathrm{~b})$ we believe that if there is any bias in our results it would be in the direction of 
underestimating the true overlap in elevational ranges of close relatives. In other words, greater taxonomic coverage would likely reinforce our conclusion that sister taxa have similar elevational distributions.

The majority of Scytalopus replacing each other along the elevation gradients we examined are distant relatives (Figure 5). The two species endemic to the Sierra Nevada de Santa Marta belong to distinct clades last sharing a common ancestor ca. 8 million years ago (clades D and $\mathrm{H}$ in Figure 2; Figure 5). Likewise, the four species occurring in forests on the Pacific slope of the Western Andes of Colombia belong to four different clades (clades D, E, F and I in Figure 3 ), whereas a fifth species ( $S$. canus) occurring in páramo habitats above treeline belongs to yet another clade (clade B). The species found above and below $S$. alvarezlopezi in the region (S. vicinior and S. chocoensis, respectively; Figure 5) belong to clade E, but they are not sister to each other. The five species replacing each other along the Amazonian slope of the Andes in Zamora-Chinchipe, Ecuador, belong to four distinct clades (B, D, H and I in Figure 3; Figure 5). Two of the species with parapatric distributions in this gradient (S. latrans and S. micropterus) are closely related, but the posterior probability of the hypothesis that they are sisters is only 0.43 . The most recent common ancestor of species occurring in elevational gradients in western Colombia, in eastern Ecuador, and in eastern Peru is the most recent common ancestor of all Scytalopus, which existed ca. 9.8 million years ago (crown age 7.8-12.3 m.a. highest posterior density; Figure 5). Taken together, the above data indicate that most species in the genus replacing each other along elevational gradients in South America did not evolve in parapatry in situ, but rather met in each gradient following divergence in allopatry.

However, the possibility of parapatric speciation remains plausible for some of the species replacing each other with elevation on the eastern slope of the Andes. In contrast to patterns observed in other regions, four of the six species replacing each other with elevation the Río Satipo Valley in Junín, Peru, belong to clade I (Figure 3; Figure 5). Moreover, three of these species (S. femoralis, S. gettyae and $S$. acutirostris) belong to a group nested within clade I including several closely allied taxa with shallow divergence in mtDNA (Figure 3; Figure 5). The remaining two species found in this gradient belong to clade B (an unidentified taxon; Hosner et al., 2013) and clade H (S. atratus). Unpublished evidence indicates a seventh species ( $S$. aff. parvirostris) belonging to clade G also occurs in the Río Satipo Valley (N. Krabbe, pers. comm.) but we did not include it in Figure 5 because information on its elevational range in the area is lacking.

\section{Discussion}

Many species of birds and other organisms have restricted elevational distributions, particularly in the tropics. This results in biodiversity patterns observable globally (e.g., tropical mountains are hotspots of species turnover in space because species replace each other with elevation; Fjeldså et al., 2012) and regionally (e.g., diversity may peak at mid elevations or decline with elevation in a given mountain; Quintero \& Jetz, 2018). We probed into evolutionary processes resulting in replacements of species along mountain slopes by examining the elevational ranges of species in the context of a phylogeny of Scytalopus tapaculos, a speciose clade of Neotropical montane birds in which the elevational replacement of species is commonplace. We found that (1) elevational ranges of species of Scytalopus are relatively narrow given the broad elevational gradients of the mountains where they live, (2) closely related species in the genus usually resemble each other in elevational distributions, (3) most pairs of sister taxa have largely overlapping elevational ranges, and (4) species coexisting regionally with elevational segregation on mountains are very often -but not alwaysdistantly related to each other. Assuming that current distributional ranges are informative about the geographic context of speciation (Barraclough \& Vogler, 2000), our study thus suggests that speciation in Scytalopus occurs predominantly in allopatry within elevational zones, and that elevational replacements typically result from secondary contact of formerly allopatric species rather than from primary divergence in parapatry (see also Arctander \& Fjeldså, 1994). However, the latter possibility cannot be entirely excluded for some species and regions.

Our analyses of phylogenetic signal in elevational ranges and of overlap in elevational ranges between sister taxa treat such ranges as if they were phenotypic attributes amenable to evolution. Although elevational ranges are not organismal traits, we consider them emergent properties of populations which do reflect heritable phenotypes allowing organisms to persist over a given range of environments, justifying our study of the evolution of such ranges in a phylogenetic 
framework (Cadena, 2007). We acknowledge, however, that because elevation per se is not a factor directly influencing organisms, one needs to exercise caution when comparing elevational distributions among species living in regions differing in the way in which elevation covaries with conditions and resources to which organisms directly respond (Cadena \& Loiselle, 2007). In this regard, we point out that some factors likely limiting organisms such as partial $\mathrm{O}_{2}$ pressure do vary consistently with elevation regardless of geographic context, but others like temperature do not. However, because closely related species of Scytalopus typically occur in the same geographic region (i.e. at similar latitudes; Cadena et al., 2019b), we believe it is generally sensible to assume that similar elevational distributions reflect similar ecology and underlying phenotypic traits.

In agreement with our results, previous work on birds (García-Moreno \& Fjeldså, 2000; Caro et al., 2013) and other animals (Patton \& Smith, 1992; Lynch, 1999) indicates that species replacing each other with elevation in the Neotropics are often not sister to each other. Furthermore, sister species in several vertebrate clades overlap considerably in their elevational ranges in Neotropical mountains (Cadena et al., 2012), suggesting that speciation occurs most often in allopatry within elevational zones and thus that elevational replacements result predominantly from secondary contact (but see Kozak \& Wiens, 2007). Work on this topic in other tropical regions has been more limited, yet evidence from Africa (Fuchs et al., 2011) and southeast Asia (Moyle et al., 2017) also indicates secondary contact is the most likely explanation for elevational replacements (but see Bryja et al., 2018; Eldridge et al., 2018). Likewise, assembly of biotas in other mountain systems often results more from colonization by lineages from other regions than from diversification within mountains (Johansson et al., 2007; Merckx et al., 2015). Therefore, understanding the processes influencing the dynamics of geographic ranges which lead to secondary sympatry following divergence in allopatry is central to establishing how diversity accumulates in montane regions.

Those unfamiliar with Scytalopus tapaculos might be unsurprised by our finding that species originating in distinct mountains may come together into regional sympatry with elevational segregation in a given mountain. After all, tapaculos are birds and birds fly around. We, however, find this result quite striking because, unlike many birds, Scytalopus are notably poor dispersers (Krabbe \& Schulenberg, 2003). Birds in the genus walk and hop much more than they fly, have tiny and rounded wings which preclude long-distance powered flight, and have even lost fused clavicles, one of the most exquisite putative adaptations of birds in general to their flighted life style. The behavior of Scytalopus also makes them highly reluctant to disperse: most species very rarely venture far from forest cover, having been described as agoraphobic (Krabbe \& Schulenberg, 1997) or photophobic (Sick, 1993). Even during storms in the high Andes, tapaculos tend to stay put: rather than moving downslope to avoid inclement weather, individuals maintain their territories and forage in tunnel systems under the snow (Fjeldså, 1991).

How did such undispersive birds manage to get around, colonizing an isolated mountain system like the Sierra Nevada de Santa Marta twice or the two slopes of the northern Andes multiple times? Tapaculos are not alone in achieving such feats. Phylogeographic analyses of Henicorhina wood-wrens (Troglodytidae), another group of poorly dispersive birds, also revealed that elevational replacements result from secondary contact of formerly allopatric lineages (Caro et al., 2013; Cadena et al., 2019a). An explanation for the apparent paradox of poor dispersers repeatedly coming into contact from disjunct areas, even in highly isolated mountains, is that individual birds did not disperse over large distances crossing barriers now appearing unsurmountable. Rather, populations likely tracked the dynamics of their favored environments, gradually expanding their geographic distributions in concert with climatic change. During cool periods in Earth history, montane environments in tropical mountains were displaced downslope, which increased opportunities for formerly isolated areas to become connected by vegetation; in turn, isolation among such areas likely increased during warmer periods when vegetation zones retreated upslope (Hooghiemstra \& Van der Hammen, 2004; Bush et al., 2011). Repeated cycles of disconnection and connection of montane areas (Ramírez-Barahona \& Eguiarte, 2013) may thus have spurred cycles of allopatric speciation and subsequent secondary contact, thereby enabling the regional accumulation of diversity (Roy et al., 1997). Owing to the expected narrow thermal tolerance of tropical montane organisms (Janzen, 1967), one would expect this mechanism of divergence and accumulation of diversity in mountains to be especially prevalent in the tropics (Ghalambor et al., 2006; Kozak \& Wiens, 2007; Cadena et al., 2012). An alternative, nonexclusive explanation for cycles of allopatric speciation followed by establishment of secondary sympatry, is that species may go through phases of expansion and contraction of their geographic ranges even in the absence of marked changes in the 
physical environment (Cadena et al., 2019a). This may occur owing to evolution of phenotypic traits influencing dispersal (Hosner et al., 2017), or to changes in ecological specialization and interactions with other species (Ricklefs, 2010).

Although adaptation to divergent selective pressures along gradients of elevation may seem like a prime precursor to the origin of new species (e.g. Funk et al., 2016; Hua, 2016), parapatric speciation along mountain slopes appears to be rare. In contrast to data discussed above, several studies do suggest that species replacing each other along elevational gradients may be closely related (Bates \& Zink, 1994; Hall, 2005; DuBay \& Witt, 2012), yet evidence that these replacements do not reflect separate colonization events of elevation belts or lowland-highland vicariance resulting from uplift processes (Brumfield \& Edwards, 2007; Ribas et al., 2007; Santos et al., 2009) is lacking. To our knowledge, the clearest example of parapatric speciation in mountains involves sister species in the plant genus Senecio occurring on Mount Etna, Italy, which differ strikingly in ecology and phenotype despite experiencing extensive gene flow (Chapman et al., 2013; Osborne et al., 2013; Chapman et al., 2016). A promising additional case is that of Syma kingfishers in New Guinea, in which two distinct species co-occuring with elevational segregation have experienced gene flow yet maintain divergence in regions of the genome likely involved in adaptation and, presumably, mate choice (Linck et al., 2019). In contrast to the Senecio and Syma examples, avian taxa replacing each other with elevation in Neotropical mountains seldom show evidence of gene flow, with the only documented cases of interbreeding between elevational replacements in the region we are aware of being those of Anairetes tit-tyrants in Peru (Dubay \& Witt, 2014), Myiarchus flycatchers in Bolivia (Lanyon, 1978), Henicorhina wood-wrens in Ecuador (Halfwerk et al., 2016), and Ramphocelus tanagers in Colombia (Sibley, 1958; Morales-Rozo et al., 2017). The apparent paucity of hybridization between birds replacing each other with elevation in the Neotropics further suggests that elevational replacements did not originate through primary divergence in parapatry in the absence of barriers to gene flow, but instead via secondary contact of reproductively isolated populations. However, our inference of lack of hybridization between elevational replacements in the Andes is largely based on patterns of phenotypic variation; in most cases it remains to be seen whether genetic data reveal cryptic gene flow (Weir et al., 2015).

While we cannot reject the hypothesis that closely allied species of Scytalopus replacing each other along the eastern slope of the Andes colonized such regions independently, our analyses indicate that parapatric speciation along the elevational gradient may have occurred there. Several of the species replacing each other with elevation in the Satipo Valley of Peru are closely related to each other, belonging to a clade of relatively recent origin in which mtDNA divergence is shallow and rates of speciation appear faster than in the rest of the genus (Cadena et al., 2019b). Two members of this clade, S. latrans and S. micropterus, also replace each other with elevation in eastern Ecuador and Colombia. Because shallow divergence in putatively neutral loci and high rates of speciation may reflect rapid divergence mediated by adaptation in the face of gene flow, future studies should explicitly test predictions of ecological speciation (Smith et al., 2005) to determine whether elevational replacements on the eastern Andean slope may indeed be uniquely explained by parapatric divergence. The same is true for the western slope of the northern Andes, where phylogeographic patterns suggest parapatric speciation may have occurred in amphibians and reptiles (Arteaga et al., 2016; Guayasamin et al., 2017).

Beyond examining patterns of relationships among species and populations, studies of the mechanisms underlying adaptation and of how adaptive evolution in the face of gene flow may lead to speciation along elevational gradients are needed (see Hua, 2016 for a theoretical perspective). In birds, for example, putatively adaptive variation with elevation has been documented in various traits influencing functions such as respiratory physiology (Scott, 2011; Dawson et al., 2016; York et al., 2017), thermoregulation (Scott et al., 2008; Symonds \& Tattersall, 2010), foraging (Kleindorfer et al., 2006; McCormack \& Smith, 2008), locomotion (Altshuler et al., 2004; Milá et al., 2009), and vocal signalling (Dingle et al., 2008; Kirschel et al., 2009). Whether any of such selective pressures may account for speciation by directly or pleiotropically influencing mating patterns in Scytalopus in the eastern Andean slope and in other groups is essentially unknown.

Given that elevational replacements more often reflect secondary contact than parapatric divergence, a central question involving the origin of non-overlapping ranges characterizing many species assemblages from tropical mountains remains unanswered. Do contrasting elevational distributions of species originate in allopatry or upon secondary contact? Diamond (1973) reasoned that elevational parapatry reflects the outcome of competitive interactions, whereby 
interspecific competition between formerly isolated species favors divergence of elevational ranges when they come into contact. Alternatively, contrasting elevational ranges may arise in allopatry, with the non-overlapping ranges of species one observes reflecting sorting processes, such that only species differing in elevational ranges a priori may successfully attain regional sympatry with segregation along mountain slopes (Cadena, 2007; McEntee et al., 2018). A recent analysis revealed that sympatric sister species of birds in the tropics have more different elevational ranges than allopatric sister species regardless of their age, which was interpreted as evidence in favor of the hypothesis that elevational divergence is driven by competition upon secondary contact (Freeman, 2015). While abutting elevational ranges may indeed be maintained by competition in some cases (Cadena \& Loiselle, 2007; Jankowski et al., 2010; Freeman \& Montgomery, 2016), other biotic and abiotic forces may also mediate species turnover with elevation (Elsen et al., 2017). Moreover, because most cases of elevational replacements do not involve sister species, more work is necessary to determine the geographic context in which contrasting elevational ranges arise. Analyses incorporating species interactions into models of trait evolution (Nuismer \& Harmon, 2015) while jointly considering the potential for such interactions to occur given geographic distributions of species (Drury et al., 2016; Clarke et al., 2017) would be a fruitful avenue for future studies on the topic (Quintero \& Landis, 2019). Other mechanisms through which elevational distributions of species may change including tectonic processes of uplift or subsidence which may displace organisms vertically in passive fashion also merit consideration (Heads, 1989, 2005; Ribas et al., 2007). Scytalopus tapaculos are well suited for additional studies on the dynamics of elevational ranges integrating ecology, evolution, and Earth history.

\section{Acknowledgments}

We thank Ana Carnaval and Valentí Rull for inviting us to contribute this chapter. Andrés Cuervo, Niels Krabbe, Daniel Lane, Thomas Schulenberg, and V. Piacentini shared valuable information on the distributions of tapaculos. We are grateful to Ana Carnaval, Santiago Herrera, Ethan Linck, Ignacio Quintero, Glenn Seeholzer, Felipe Zapata, an anonymous reviewer, and CDC's laboratory group for helpful discussion and comments on the manuscript. Fernando Ayerbe kindly allowed us to use his illustrations of birds in our figures. Paola Montoya, Gustavo Bravo and Elkin Tenorio provided measurement data, and Cooper French and Ethan Linck provided photographs for Figure 2. We received financial support from the Facultad de Ciencias at Universidad de los Andes (Programa de Investigación to CDC).

\section{References}

American Ornithologists' Union. (1998) Checklist of North American birds, '7th edition. American Ornithologists' Union, Washington, DC.

Altshuler, D.L., Dudley, R. \& McGuire, J.A. (2004) Resolution of a paradox: hummingbird flight at high elevation does not come without a cost. Proceedings of the National Academy of Sciences of the USA, 101, 1773117736 .

Arctander, P. (1995) Comparison of a mitochondrial gene and a corresponding nuclear pseudogene. Proceedings of the Royal Society of London B, 262, 13-19.

Arctander, P. \& Fjeldså, J. (1994) Andean tapaculos of the genus Scytalopus (Aves, Rhinocryptidae): a study of speciation using DNA sequence data. Conservation Genetics (ed. by V. Loeschcke, J. Tomiuk and S.K. Jain), pp. 205-225. Birkhauser Verlag, Basel, Switzerland.

Arteaga, A., Pyron, R.A., Peñafiel, N., Romero-Barreto, P., Culebras, J., Bustamante, L., Yánez-Muñoz, M.H. \& Guayasamin, J.M. (2016) Comparative phylogeography reveals cryptic diversity and repeated patterns of cladogenesis for amphibians and reptiles in northwestern Ecuador. PLoS One, 11, e0151746.

Avendaño, J.E. \& Donegan, T.M. (2015) A distinctive new subspecies of Scytalopus griseicollis (Aves, Passeriformes, Rhinocryptidae) from the northern Eastern Cordillera of Colombia and Venezuela. ZooKeys, 506, 137-153.

Avendaño, J.E., Cuervo, A.M., López-O., J.P., Gutiérrez-Pinto, N., Cortés-Diago, A. \& Cadena, C.D. (2015) A new species of tapaculo (Rhinocryptidae: Scytalopus) from the Serranía de Perijá of Colombia and Venezuela. Auk, 132, 450-466.

Ayerbe-Quiñones, F. (2018) Guía ilustrada de la avifauna colombiana. Wildlife Conservation Society, Bogotá, Colombia. 
Badgley, C., Smiley, T.M. \& Cable, R. (2018) Mountains, climate and mammals. Mountains, Climate and Biodiversity (ed. by C. Hoorn, A. Perrigo and A. Antonelli). John Wiley \& Sons.

Barraclough, T.G. \& Vogler, A.P. (2000) Detecting the geographical pattern of speciation from species-level phylogenies. American Naturalist, 155, 419-434.

Bates, J.M. \& Zink, R.M. (1994) Evolution into the Andes: molecular evidence for species relationships in the genus Leptopogon. Auk, 111, 507-515.

Blomberg, S.P., Garland, T. \& Ives, A.R. (2003) Testing for phylogenetic signal in comparative data: behavioral traits are more labile. Evolution, 57, 717-745.

Bornschein, M.R., Maurício, G.N., Belmonte-Lopes, R., Mata, H. \& Bonatto, S.L. (2007) Diamantina Tapaculo, a new Scytalopus endemic to the Chapada Diamantina, northeastern Brazil (Passeriformes: Rhinocryptidae). Revista Brasileira de Ornitologia, 15, 151-174.

Bouckaert, R., Heled, J., Kühnert, D., Vaughan, T., Wu, C.-H., Xie, D., Suchard, M.A., Rambaut, A. \& Drummond, A.J. (2014) BEAST 2: A Software Platform for Bayesian Evolutionary Analysis. PLOS Computational Biology, 10, e1003537.

Brumfield, R.T. \& Edwards, S.V. (2007) Evolution into and out of the Andes: a Bayesian analysis of historical diversification in Thamnophilus antshrikes. Evolution, 61, 346-367.

Bryja, J., Kostin, D., Meheretu, Y., Šumbera, R., Bryjová, A., Kasso, M., Mikula, O. \& Lavrenchenko, L.A. (2018) Reticulate Pleistocene evolution of Ethiopian rodent genus along remarkable altitudinal gradient. Molecular Phylogenetics and Evolution, 118, 75-87.

Bush, M.B., Hanselman, J.A. \& Hooghiemstra, H. (2011) Andean montane forests and climate change. Tropical Rainforest Responses to Climatic Change (Second Edition) (ed. by M.B. Bush, J.R. Flenley and W.D. Gosling), pp. 35-60. Springer-Verlag, Berlin.

Cadena, C.D. (2007) Testing the role of interspecific competition in the evolutionary origin of elevational zonation: an example with Buarremon brush-finches (Aves, Emberizidae) in the neotropical mountains. Evolution, 61, $1120-1136$.

Cadena, C.D. \& Loiselle, B.A. (2007) Limits to elevational distributions in two species of emberizine finches: Disentangling the role of interspecific competition, autoecology, and geographic variation in the environment. Ecography, 30, 491-504.

Cadena, C.D., Pérez-Emán, J.L., Cuervo, A.M., Céspedes, L.N., Epperly, K.L. \& Klicka, J.T. (2019a) Extreme genetic structure and dynamic range evolution in a montane passerine bird: implications for tropical diversification. Biological Journal of the Linnean Society, 126, 487-506.

Cadena, C.D., Cuervo, A.M., Céspedes, L.N., Bravo, G.A., Krabbe, N., Schulenberg, T.S., Derryberry, G.E., Silveira, L.F., Derryberry, E.P., Brumfield, R.T. \& Fjeldså, J. (2019b) Systematics, biogeography and diversification of Scytalopus tapaculos (Rhinocryptidae), an enigmatic radiation of Neotropical montane birds. bioRxiv, https://doi.org/10.1101/600775

Cadena, C.D., Kozak, K.H., Gómez, J.P., Parra, J.L., McCain, C.M., Bowie, R.C.K., Carnaval, A.C., Moritz, C., Rahbek, C., Roberts, T.E., Sanders, N.J., Schneider, C.J., VanDerWal, J., Zamudio, K.R. \& Graham, C.H. (2012) Latitude, elevational climatic zonation, and speciation in New World vertebrates. Proceedings of the Royal Society of London B, 279, 194-201.

Caro, L.M., Caycedo-Rosales, P.C., Bowie, R.C.K., Slabbekoorn, H. \& Cadena, C.D. (2013) Ecological speciation along an elevational gradient in a tropical passerine bird? Journal of Evolutionary Biology, 26, 357-374.

Chapman, F.M. (1917) The distribution of bird-life in Colombia; a contribution to a biological survey of South America. Bulletin of the American Museum of Natural History, 36, 1-169.

Chapman, F.M. (1926) The distribution of bird-life in Ecuador: a contribution to a study of the origin of Andean birdlife. Bulletin of the American Museum of Natural History, 55, 1-784.

Chapman, M.A., Hiscock, S.J. \& Filatov, D.A. (2013) Genomic divergence during speciation driven by adaptation to altitude. Molecular Biology and Evolution, 30, 2553-2567.

Chapman, M.A., Hiscock, S.J. \& Filatov, D.A. (2016) The genomic bases of morphological divergence and reproductive isolation driven by ecological speciation in Senecio (Asteraceae). Journal of Evolutionary Biology, 29, 98-113.

Claramunt, S., Derryberry, E.P., Remsen, J.V., Jr. \& Brumfield, R.T. (2012) High dispersal ability inhibits speciation in a continental radiation of passerine birds. Proceedings of the Royal Society of London B, 279, 1567-1574. 
Clarke, M., Thomas, G.H. \& Freckleton, R.P. (2017) Trait evolution in adaptive radiations: modeling and measuring interspecific competition on phylogenies. American Naturalist, 189, 121-137.

Cuervo, A.M., Cadena, C.D., Krabbe, N. \& Renjifo, L.M. (2005) Scytalopus stilesi, a new species of tapaculo (Rhinocryptidae) from the Cordillera Central of Colombia. Auk, 122, 445-463.

Dawson, N.J., Ivy, C.M., Alza, L., Cheek, R., York, J.M., Chua, B., Milsom, W.K., McCracken, K.G. \& Scott, G.R. (2016) Mitochondrial physiology in the skeletal and cardiac muscles is altered in torrent ducks, Merganetta armata, from high altitudes in the Andes. The Journal of Experimental Biology, 219, 3719-3728.

del Hoyo, J., Elliott, A., Sargatal, J., Christie, D.A. \& de Juana, E. (2018) Handbook of the Birds of the World Alive. Lynx Edicions (retrieved from http://www.hbw.com/ on [18/09/2018]). Barcelona.

Diamond, J.M. (1973) Distributional ecology of New Guinea birds. Science, 179, 759-769.

Dingle, C., Halfwer, W. \& Slabbekoorn, H. (2008) Habitat-dependent song divergence at subspecies level in the greybreasted wood-wren. Journal of Evolutionary Biology, 21, 1079-1089.

Donegan, T.M. \& Avendaño-C., J.E. (2008) Notes on tapaculos (Passeriformes: Rhinocryptidae) of the Eastern Andes of Colombia and the Venezuelan Andes, with a new subspecies of Scytalopus griseicollis from Colombia. Ornitología Colombiana, 6, 24-65.

Donegan, T.M., Avendaño, J.E. \& Lambert, F. (2013) A new tapaculo related to Scytalopus rodriguezi from Serranía de los Yariguíes, Colombia. Bulletin of the British Ornithologists' Club, 133, 256-271.

Drury, J., Clavel, J., Manceau, M. \& Morlon, H. (2016) Estimating the effect of competition on trait evolution using maximum likelihood inference. Systematic Biology, 65, 700-710.

DuBay, S.G. \& Witt, C.C. (2012) An improved phylogeny of the Andean tit-tyrants (Aves, Tyrannidae): More characters trump sophisticated analyses. Molecular Phylogenetics and Evolution, 64, 285-296.

Dubay, S.G. \& Witt, C.C. (2014) Differential high-altitude adaptation and restricted gene flow across a mid-elevation hybrid zone in Andean tit-tyrant flycatchers. Molecular Ecology, 23, 3551-3565.

Eldridge, R.A., Achmadi, A.S., Giarla, T.C., Rowe, K.C. \& Esselstyn, J.A. (2018) Geographic isolation and elevational gradients promote diversification in an endemic shrew on Sulawesi. Molecular Phylogenetics and Evolution, 118, 306-317.

Elsen, P.R., Tingley, M.W., Kalyanaraman, R., Ramesh, K. \& Wilcove, D.S. (2017) The role of competition, ecotones, and temperature in the elevational distribution of Himalayan birds. Ecology, 98, 337-348.

Endler, J.A. (1982) Problems in distinguishing historical from ecological factors in biogeography. American Zoologist, 22, 441-452.

Fjeldså, J. (1991) The activity of birds during snow-storms in high-level woodlands in Peru. Bulletin of the British Ornithologists' Club, 111, 4-11.

Fjeldså, J. \& Krabbe, N. (1990) Birds of the high Andes. Zoological Museum, University of Copenhagen and Apollo Books, Svendborg, Denmark.

Fjeldså, J., Bowie, R.C.K. \& Rahbek, C. (2012) The role of mountain ranges in the diversification of birds. Annual Review of Ecology, Evolution and Systematics, 43, 249-265.

Freeman, B. (2015) Competitive interactions upon secondary contact drive elevational divergence in tropical birds. American Naturalist, 186, 470-479.

Freeman, B.G. \& Montgomery, G. (2016) Interspecific aggression by the Swainson's Thrush (Catharus ustulatus) may limit the distribution of the threatened Bicknell's Thrush (Catharus bicknelli) in the Adirondack Mountains. Condor, 118, 168-178.

Fuchs, J., Fjeldså, J. \& Bowie, R.C.K. (2011) Diversification across an altitudinal gradient in the Tiny Greenbul (Phyllastrephus debilis) from the Eastern Arc Mountains of Africa. BMC Evolutionary Biology, 11, 117.

Funk, W.C., Murphy, M.A., Hoke, K.L., Muths, E., Amburgey, S.M., Lemmon, E.M. \& Lemmon, A.R. (2016) Elevational speciation in action? Restricted gene flow associated with adaptive divergence across an altitudinal gradient. Journal of Evolutionary Biology, 29, 241-252.

Gadek, C.R., Newsome, S.D., Beckman, E.J., Chavez, A.N., Galen, S.C., Bautista, E. \& Witt, C.C. (2018) Why are tropical mountain passes "low" for some species? Genetic and stable-isotope tests for differentiation, migration and expansion in elevational generalist songbirds. Journal of Animal Ecology, 87, 741-753.

García-Moreno, J. \& Fjeldså, J. (2000) Chronology and mode of speciation in the Andean avifauna. Isolated Vertebrate Communities in the Tropics (ed. by G. Rheinwald), pp. 25-46. Proc. 4th Int. Symp, Bonn. Zool. Monogr. 46, Bonn. 
García-Robledo, C., Kuprewicz, E.K., Staines, C.L., Erwin, T.L. \& Kress, W.J. (2016) Limited tolerance by insects to high temperatures across tropical elevational gradients and the implications of global warming for extinction. Proceedings of the National Academy of Sciences of the USA, 113, 680-685.

Ghalambor, C., Huey, R.B., Martin, P.R., Tewksbury, J.J. \& Wang, G. (2006) Are mountain passes higher in the tropics? Janzen's hypothesis revisited. Integrative and Comparative Biology, 46, 5-17.

Gill, B.A., Kondratieff, B.C., Casner, K.L., Encalada, A.C., Flecker, A.S., Gannon, D.G., Ghalambor, C.K., Guayasamin, J.M., Poff, N.L., Simmons, M.P., Thomas, S.A., Zamudio, K.R. \& Funk, W.C. (2016) Cryptic species diversity reveals biogeographic support for the 'mountain passes are higher in the tropics' hypothesis. Proceedings of the Royal Society B: Biological Sciences, 283, 20160553.

Graves, G.R. (1988) Linearity of geographic range and its possible effect on the population structure of Andean birds. Auk, 105, 47-52.

Guayasamin, J.M., Hutter, C.R., Tapia, E.E., Culebras, J., Peñafiel, N., Pyron, R.A., Morochz, C., Funk, W.C. \& Arteaga, A. (2017) Diversification of the rainfrog Pristimantis ornatissimus in the lowlands and Andean foothills of Ecuador. PLoS One, 12, e0172615.

Halfwerk, W., Dingle, C., Brinkhuizen, D.M., Poelstra, J.W., Komdeur, J. \& Slabbekoorn, H. (2016) Sharp acoustic boundaries across an altitudinal avian hybrid zone despite asymmetric introgression. Journal of Evolutionary Biology, 29, 1356-1367.

Hall, J.P.W. (2005) Montane speciation patterns in Ithomiola butterflies (Lepidoptera: Riodinidae): are they consistently moving up in the world? Proceedings of the Royal Society of London B, 272, 2457-2466.

Hazzi, N.A., Moreno, J.S., Ortiz-Movliav, C. \& Palacio, R.D. (2018) Biogeographic regions and events of isolation and diversification of the endemic biota of the tropical Andes. Proceedings of the National Academy of Sciences of the United States of America, 115, 7985-7990.

Heads, M. (1989) Integrating earth and life sciences in New Zealand natural history: the parallel arcs model. New Zealand Journal of Zoology, 16, 549-585.

Heads, M. (2005) Towards a panbiogeography of the seas. Biological Journal of the Linnean Society, 84, 675-723.

Herzog, S.K., Terril, R.S., Jahn, A.E., Remsen Jr., J.V., Maillard Z., O., García-Solíz, V.H., MacLeod, R., Maccormick, A. \& Vidoz, J.Q. (2016) Birds of Bolivia: Field Guide. Asociación Armonía.

Hilty, S.L. (2003) Birds of Venezuela, Second Edition. Princeton University Press, Princeton, NJ.

Hooghiemstra, H. \& Van der Hammen, T. (2004) Quaternary ice-age dynamics in the Colombian Andes: developing an understanding of our legacy. Philosophical Transactions of the Royal Society of London B, 359, 173-181.

Hosner, P.A., Robbins, M.B., Valqui, T. \& Peterson, A.T. (2013) A new species of Scytalopus tapaculo (Aves: Passeriformes: Rhinocryptidae) from the Andes of Central Peru. Wilson Journal of Ornithology, 125, $233-242$.

Hosner, P.A., Tobias, J.A., Braun, E.L. \& Kimball, R.T. (2017) How do seemingly non-vagile clades accomplish transmarine dispersal? Trait and dispersal evolution in the landfowl (Aves: Galliformes). Proceedings of the Royal Society of London B, 284, 20170210.

Hua, X. (2016) The impact of seasonality on niche breadth, distribution range and species richness: a theoretical exploration of Janzen's hypothesis. Proceedings of the Royal Society of London B, 283, 20160349.

Huey, R.B. (1978) Latitudinal pattern of between-altitude faunal similarity: mountains might be higher in the tropics. American Naturalist, 112, 225-229.

Jankowski, J.E., Robinson, S.K. \& Levey, D.J. (2010) Squeezed at the top: Interspecific aggression may constrain elevational ranges in tropical birds. Ecology, 91, 1877-1884.

Jankowski, J.E., Londoño, G.A., Robinson, S.K. \& Chapell, M.A. (2013a) Exploring the role of physiology and biotic interactions in determining elevational ranges of tropical animals. Ecography, 36, 1-12.

Jankowski, J.E., Merkrod, C.L., Farfan Rios, W., García Cabrera, K., Salinas Revilla, N. \& Silman, M.R. (2013b) The relationship of tropical bird communities to tree species composition and vegetation structure along an Andean elevational gradient. Journal of Biogeography, 40, 950-962.

Janzen, D.H. (1967) Why mountain passes are higher in the tropics. American Naturalist, 101, 233-249.

Johansson, U.S., Alstrom, P., Olsson, U., Ericson, P.G.P., Sundberg, P. \& Price, T.D. (2007) Build-up of the Himalayan avifauna through immigration: a biogeographical analysis of the Phylloscopus and Seicercus warblers. Evolution, 61, 324-333.

Kessler, M. (2001) Patterns of diversity and range size of selected plant groups along an elevational transect in the Bolivian Andes. Biodiversity and Conservation, 10, 1897-1921. 
Kirschel, A.N.G., Blumstein, D.T., Cohen, R.E., Buermann, W., Smith, T.B. \& Slabbekoorn, H. (2009) Birdsong tuned to the environment: green hylia song varies with elevation, tree cover, and noise. Behavioral Ecology, 20, 1089-1095.

Kleindorfer, S., Chapman, T.W., Winkler, H. \& Sulloway, F.J. (2006) Adaptive divergence in contiguous populations of Darwin's Small Ground Finch (Geospiza fuliginosa). Evolutionary Ecology Research, 8, 357-372.

Kozak, K.H. \& Wiens, J.J. (2007) Climatic zonation drives latitudinal variation in speciation mechanisms. Proceedings of the Royal Society of London B, 274, 2995-3003.

Krabbe, N. \& Schulenberg, T.S. (1997) Species limits and natural history of Scytalopus tapaculos (Rhinocryptidae), with descriptions of Ecuadorian taxa, including three new species. Ornithological Monographs, 48, 47-88.

Krabbe, N. \& Schulenberg, T.S. (2003) Family Rhinocryptidae (Tapaculos). Handbook of the birds of the world, volume 8: broadbills to tapaculos (ed. by J. Del Hoyo, A. Elliott and D. Christie), pp. 748-787. Lynx Edicions, Barcelona.

Krabbe, N. \& Cadena, C.D. (2010) A taxonomic revision of the Paramo Tapaculo Scytalopus canus Chapman (Aves: Rhinocryptidae), with description of a new subspecies from Ecuador and Peru. Zootaxa, 2354, 56-66.

Krabbe, N., Salaman, P., Cortés, A., Quevedo, A., Ortega, L.A. \& Cadena, C.D. (2005) A new species of Scytalopus tapaculo from the upper Magdalena Valley, Colombia. Bulletin of the British Ornithologists' Club, 125, 93108.

Lanyon, W.E. (1978) Revision of the Myiarchus flycatchers of South America. Bulletin of the American Museum of Natural History, 161, 427-628.

Linck, E., Freeman, B.G. \& Dumbacher, J.P. (2019) Speciation with gene flow across an elevational gradient in New Guinea kingfishers. bioRxiv, https://doi.org/10.1101/589044

Losos, J.B. \& Glor, R.E. (2003) Phylogenetic comparative methods and the geography of speciation. Trends in Ecology and Evolution, 18, 220-227.

Lynch, J.D. (1999) Ranas pequeñas, la geometría de evolución, y la especiación en los Andes colombianos. Revista de la Academia Colombiana de Ciencias Exactas, Físicas y Naturales, 23, 143-159.

Maurício, G.N. (2005) Taxonomy of southern populations in the Scytalopus speluncae group, with description of a new species and remarks on the systematics and biogeography of the complex (Passeriformes: Rhinocryptidae). Ararajuba, 13, 7-28.

Maurício, G.N., Mata, H., Bornschein, M.R., Cadena, C.D., Alvarenga, H. \& Bonatto, S.L. (2008) Hidden generic diversity in Neotropical birds: molecular and anatomical data support a new genus for the "Scytalopus" indigoticus species-group (Aves: Rhinocryptidae). Molecular Phylogenetics and Evolution, 49, 125-135.

Maurício, G.N., Belmonte-Lopes, R., Pacheco, J.F., Silveira, L.F., Whitney, B.M. \& Bornschein, M.R. (2014) Taxonomy of "Mouse-colored Tapaculos" (II): An endangered new species from the montane Atlantic Forest of southern Bahia, Brazil (Passeriformes: Rhinocryptidae: Scytalopus). Auk, 131, 643-659.

McCain, C.M. (2009) Vertebrate range sizes indicate that mountains may be 'higher' in the tropics. Ecology Letters, $12,550-560$.

McCormack, J.E. \& Smith, T.B. (2008) Niche expansion leads to small-scale adaptive divergence along an elevation gradient in a medium-sized passerine bird. Proceedings of the Royal Society of London B, 275, 2155-2164.

McEntee, J.P., Tobias, J.A., Sheard, C. \& Burleigh, J.G. (2018) Tempo and timing of ecological trait divergence in bird speciation. Nature Ecology \& Evolution, 2, 1120-1127.

Melo, A.S., Rangel, T.F.L.V.B. \& Diniz-Filho, J.A.F. (2009) Environmental drivers of beta-diversity patterns in NewWorld birds and mammals. Ecography, 32, 226-236.

Merckx, V.S.F.T., Hendriks, K.P., Beentjes, K.K., Mennes, C.B., Becking, L.E., Peijnenburg, K.T.C.A., Afendy, A., Arumugam, N., de Boer, H., Biun, A., Buang, M.M., Chen, P.-P., Chung, A.Y.C., Dow, R., Feijen, F.A.A., Feijen, H., Soest, C.F.-v., Geml, J., Geurts, R., Gravendeel, B., Hovenkamp, P., Imbun, P., Ipor, I., Janssens, S.B., Jocqué, M., Kappes, H., Khoo, E., Koomen, P., Lens, F., Majapun, R.J., Morgado, L.N., Neupane, S., Nieser, N., Pereira, J.T., Rahman, H., Sabran, S., Sawang, A., Schwallier, R.M., Shim, P.-S., Smit, H., Sol, N., Spait, M., Stech, M., Stokvis, F., Sugau, J.B., Suleiman, M., Sumail, S., Thomas, D.C., van Tol, J., Tuh, F.Y.Y., Yahya, B.E., Nais, J., Repin, R., Lakim, M. \& Schilthuizen, M. (2015) Evolution of endemism on a young tropical mountain. Nature, 524, 347. 
Milá, B., Wayne, R.K., Fitze, P. \& Smith, T.B. (2009) Divergence with gene flow and fine-scale phylogeographical structure in the wedge-billed woodcreeper, Glyphorynchus spirurus, a Neotropical rainforest bird. Molecular Ecology, 18, 2979-2995.

Morales-Rozo, A., Tenorio, E.A., Carling, M.D. \& Cadena, C.D. (2017) Origin and cross-century dynamics of an avian hybrid zone. BMC Evolutionary Biology, 17, 257.

Moritz, C., Patton, J.L., Schneider, C.J. \& Smith, T.B. (2000) Diversification of rainforest faunas: an integrated molecular approach. Annual Review of Ecology and Systematics, 31, 533-563.

Moyle, R.G., Manthey, J.D., Hosner, P.A., Rahman, M., Lakim, M. \& Sheldon, F.H. (2017) A genome-wide assessment of stages of elevational parapatry in Bornean passerine birds reveals no introgression: implications for processes and patterns of speciation. PeerJ, 5, e3335.

Nieto, M. (2006) La obra cartográfica de Francisco José de Caldas. Universidad de los Andes, Bogotá, Colombia.

Nuismer, S.L. \& Harmon, L.J. (2015) Predicting rates of interspecific interaction from phylogenetic trees. Ecology Letters, 18, 17-27.

Osborne, O.G., Batstone, T.E., Hiscock, S.J. \& Filatov, D.A. (2013) Rapid speciation with gene flow following the formation of Mt. Etna. Genome Biology and Evolution, 5, 1704-1715.

Pagel, M. (1999) Inferring the historical patterns of biological evolution. Nature, 401, 877-884.

Parker, T.A.I., Stotz, D.F. \& Fitzpatrick, J.W. (1996) Ecological and distributional databases. Neotropical birds: ecology and conservation (ed. by D.F. Stotz, J.W. Fitzpatrick, T.a.I. Parker and D.K. Moskovits). The University of Chicago Press, Chicago.

Patterson, B.D., Stotz, D.F., Solari, S., Fitzpatrick, J.W. \& Pacheco, V. (1998) Contrasting patterns of elevational zonation for birds and mammals in the Andes of southeastern Peru. Journal of Biogeography, 25, 593-607.

Patton, J.L. \& Smith, M.F. (1992) mtDNA phylogeny of Andean mice: a test of diversification across ecological gradients. Evolution, 46, 174-183.

Phillimore, A.B., Orme, C.D.L., Thomas, G.H., Blackburn, T.M., Bennett, P.M., Gaston, K.J. \& Owens, I.P.F. (2008) Sympatric speciation in birds is rare: insights from range data and simulations. American Naturalist, 171, 646-657.

Price, T. (2008) Speciation in birds. Roberts and Company Publishers, Greenwood Village, Colorado.

Quintero, I. \& Jetz, W. (2018) Global elevational diversity and diversification of birds. Nature, 555, 246-250.

Quintero, I. \& Landis, M.J. (2019) Interdependent phenotypic and biogeographic evolution driven by biotic interactions. bioRxiv, https://doi.org/10.1101/560912

Ramírez-Barahona, S. \& Eguiarte, L.E. (2013) The role of glacial cycles in promoting genetic diversity in the Neotropics: the case of cloud forests during the Last Glacial Maximum. Ecology and Evolution, 3, 725-738.

Remsen, J.V., Jr., Areta, J.I., Cadena, C.D., Claramunt, S., Jaramillo, A., Pacheco, J.F., Robbins, M.B., Stiles, F.G., Stotz, D.F. \& Zimmer, K.J. (2018) A classification of the bird species of South America, version July 72018. American Ornithologists' Union. http://www.museum.lsu.edu/ Remsen/SACCBaseline.htm.

Restall, R., Rodner, C. \& Lentino, M. (2007) Birds of Northern South America: An Identification Guide. Volume 1: Species Accounts. Yale University Press, New Haven, CT.

Revell, L.J. (2012) phytools: an R package for phylogenetic comparative biology (and other things). Methods in Ecology and Evolution, 3, 217-223.

Revell, L.J., Harmon, L.J. \& Collar, D.C. (2008) Phylogenetic signal, evolutionary process, and rate. Systematic Biology, 57, 591-601.

Ribas, C.C., Moyle, R.G., Miyaki, C.Y. \& Cracraft, J. (2007) The assembly of montane biotas: linking Andean tectonics and climatic oscillations to independent regimes of diversification in Pionus parrots. Proceedings of the Royal Society of London B, 274, 2399-2408.

Ricklefs, R.E. (2010) Host-pathogen coevolution, secondary sympatry and species diversification. Philosophical Transactions of the Royal Society of London B, 365, 1139-1147.

Ridgely, R.S. \& Greenfield, P.J. (2001) The birds of Ecuador: status, distribution, and taxonomy. Cornell University Press, Ithaca, NY.

Roy, M.S., Silva, J.M.C., Arctander, P., García-Moreno, J. \& Fjeldså, J. (1997) The speciation of South American and African birds in montane regions. Avian molecular evolution and systematics (ed. by D.P. Mindell), pp. 325343. Academic Press, San Diego. 
Santos, J.C., Coloma, L.A., Summers, K., Caldwell, J.P., Ree, R. \& Cannatella, D.C. (2009) Amazonian amphibian diversity is primarily derived from Late Miocene Andean lineages. PLoS Biology, 7, e56.

Schulenberg, T.S., Stotz, D.F., Lane, D.F., O'Neill, J.P. \& Parker, T.A.I. (2007) Birds of Peru. Princeton University Press, Princeton, NJ.

Scott, G.R. (2011) Elevated performance: the unique physiology of birds that fly at high altitudes. The Journal of Experimental Biology, 214, 2455-2462.

Scott, G.R., Cadena, V., Tattersall, G.J. \& Milsom, W.K. (2008) Body temperature depression and peripheral heat loss accompany the metabolic and ventilatory responses to hypoxia in low and high altitude birds. Journal of Experimental Biology, 211, 1326-1335.

Sibley, C.G. (1958) Hybridization in some Colombian tanagers, avian genus "Ramphocelus". Proceedings of the American Philosophical Society, 102, 448-453.

Sick, H. (1993) Birds in Brazil: a natural history. Princeton University Press, Princeton, NJ.

Smith, B.T. \& Klicka, J. (2010) The profound influence of the Late Pliocene Panamanian uplift on the exchange, diversification, and distribution of New World birds. Ecography, 33, 333-342.

Smith, T.B., Wayne, R.K., Girman, D. \& Bruford, M.W. (2005) Evaluating the divergence-with-gene-flow model in natural populations: the importance of ecotones in rainforest speciation. Tropical rainforests: past, present, and future (ed. by E. Bermingham, C.W. Dick and C. Moritz), pp. 148-165. The University of Chicago Press, Chicago.

Stiles, F.G., Laverde-R, O. \& Cadena, C.D. (2017) A new species of tapaculo (Rhinocryptidae: Scytalopus) from the Western Andes of Colombia. Auk, 134, 377-392.

Symonds, M.R.E. \& Tattersall, G.J. (2010) Geographical variation in bill size across bird species provides evidence for Allen's rule. American Naturalist, 176, 188-197.

Team, R.C. (2018) R: A language and environment for statistical computing. R Foundation for Statistical Computing, Vienna, Austria, http://www.r-project.org/.

Terborgh, J. (1971) Distribution on environmental gradients: theory and a preliminary interpretation of distributional patterns in the avifauna of the Cordillera Vilcabamba, Peru. Ecology, 52, 23-40.

Terborgh, J. (1977) Bird species diversity on an Andean elevational gradient. Ecology, 58, 1007-1019.

Terborgh, J. \& Weske, J.S. (1975) The role of competition in the distribution of Andean birds. Ecology, 56, 562-576.

Todd, W.E.C. \& Carriker, M.A., Jr. (1922) The birds of the Santa Marta region of Colombia: a study in altitudinal distribution. Annals of the Carnegie Museum, 14, 1-611.

U., A.O. (1998) Checklist of North American birds, 7th edition. American Ornithologists' Union, Washington, DC.

Vasconcelos, M.F., Maurício, G.N., Kirwan, G.M. \& Silveira, L.F. (2008) Range extension for Marsh Tapaculo Scytalopus iraiensis to the highlands of Minas Gerais, Brazil, with an overview of the species'distribution. Bulletin of the British Ornithologists' Club, 128, 101-106.

von Humboldt, A. \& Bonpland, A. (2009) Essay on the geography of plants - with a physical tableau of the equinoctial regions (1807). Essay on the geography of plants (ed. by S.T. Jackson), pp. 61-155. University of Chicago Press, Chicago.

Wake, D.B. \& Lynch, J.F. (1976) The distribution, ecology, and evolutionary history of plethodontid salamanders in tropical America. Science Bulletin Natural History Museum of Los Angeles County, 25, 1-65.

Weir, J.T., Faccio, M.S., Pulido-Santacruz, P., Barrera-Guzmán, A.O. \& Aleixo, A. (2015) Hybridization in headwater regions, and the role of rivers as drivers of speciation in Amazonian birds. Evolution, 69, 1823-1834.

Whitney, B.M. (1994) A new Scytalopus tapaculo (Rhinocryptidae) from Bolivia, with notes on other Bolivian members of the genus and the magellanicus complex. Wilson Bulletin, 106, 585-614.

Whitney, B.M., Vasconcelos, M.F., Silveira, L.F. \& Pacheco, J.F. (2010) Scytalopus petrophilus (Rock Tapaculo): a new species from Minas Gerais, Brazil. Revista Brasileira de Biologia, 18, 73-88.

York, J.M., Chua, B.A., Ivy, C.M., Alza, L., Cheek, R., Scott, G.R., McCracken, K.G., Frappell, P.B., Dawson, N.J., Laguë, S.L. \& Milsom, W.K. (2017) Respiratory mechanics of eleven avian species resident at high and low altitude. The Journal of Experimental Biology, 220, 1079-1089. 
bioRxiv preprint doi: https://doi.org/10.1101/606558; this version posted May 6, 2019. The copyright holder for this preprint (which was not certified by peer review) is the author/funder, who has granted bioRxiv a license to display the preprint in perpetuity. It is made available under aCC-BY-NC 4.0 International license.
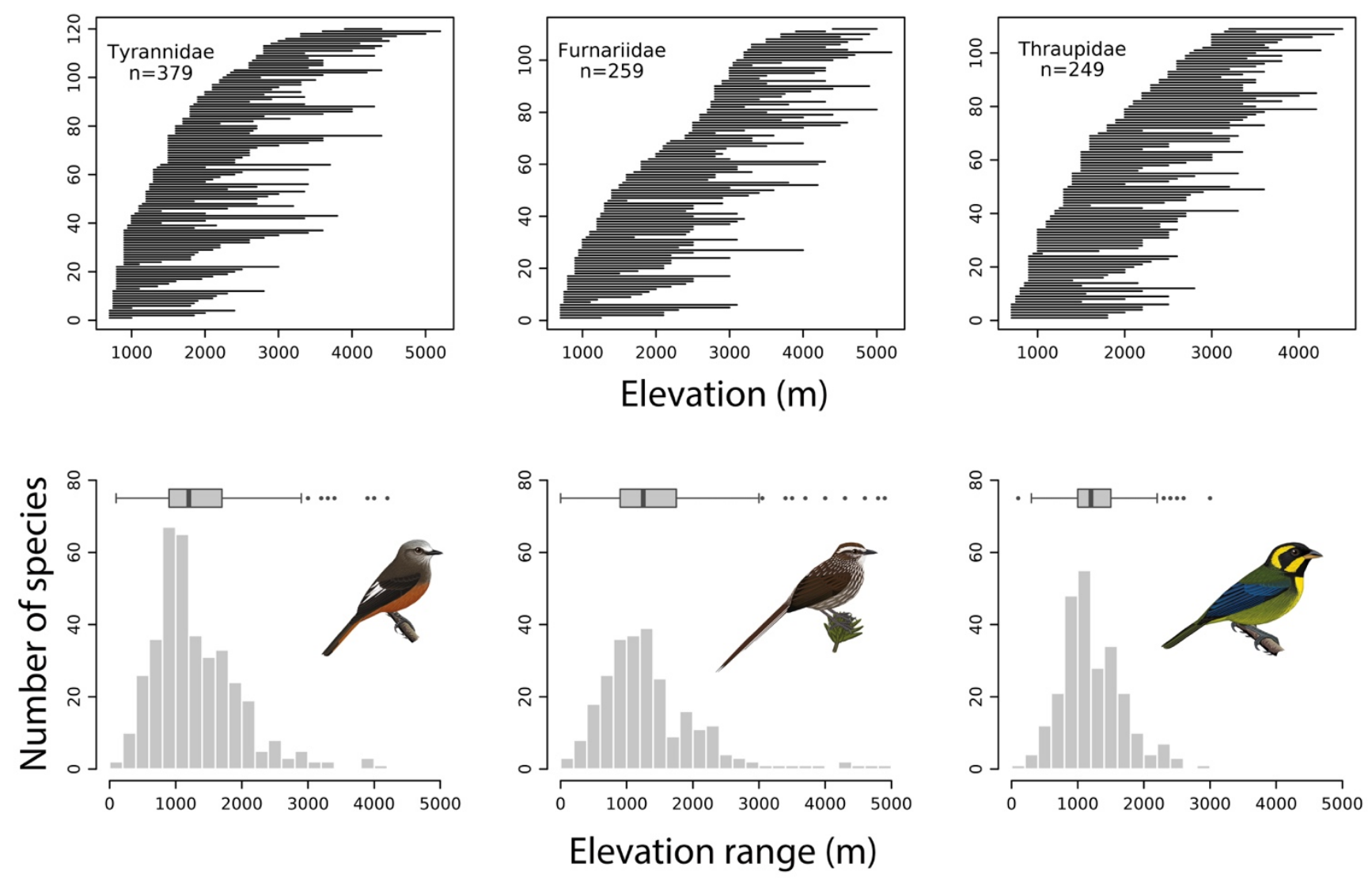

Figure 1. Restricted elevational distributions of species in three diverse families of Neotropical birds: ovenbirds (Furnariidae), tyrant flycatchers (Tyrannidae), and tanagers (Thraupidae). The panels in the top row depict the range of elevations occupied by species with lower elevational limits at or above $700 \mathrm{~m}$ ordered from lowest to highest along the vertical axis, showing turnover of species with elevation. Panels in the bottom row summarize the data above with histograms and boxplots, indicating that most species inhabit only a fraction of the elevational ranges existing on mountains like the Andes; across the three families, median elevational ranges span only ca. $1100 \mathrm{~m}$ and very few species have ranges greater than $2500 \mathrm{~m}$. Data are from Parker et al. (1996) and illustrations from Ayerbe-Quiñones (AyerbeQuiñones, 2018). 


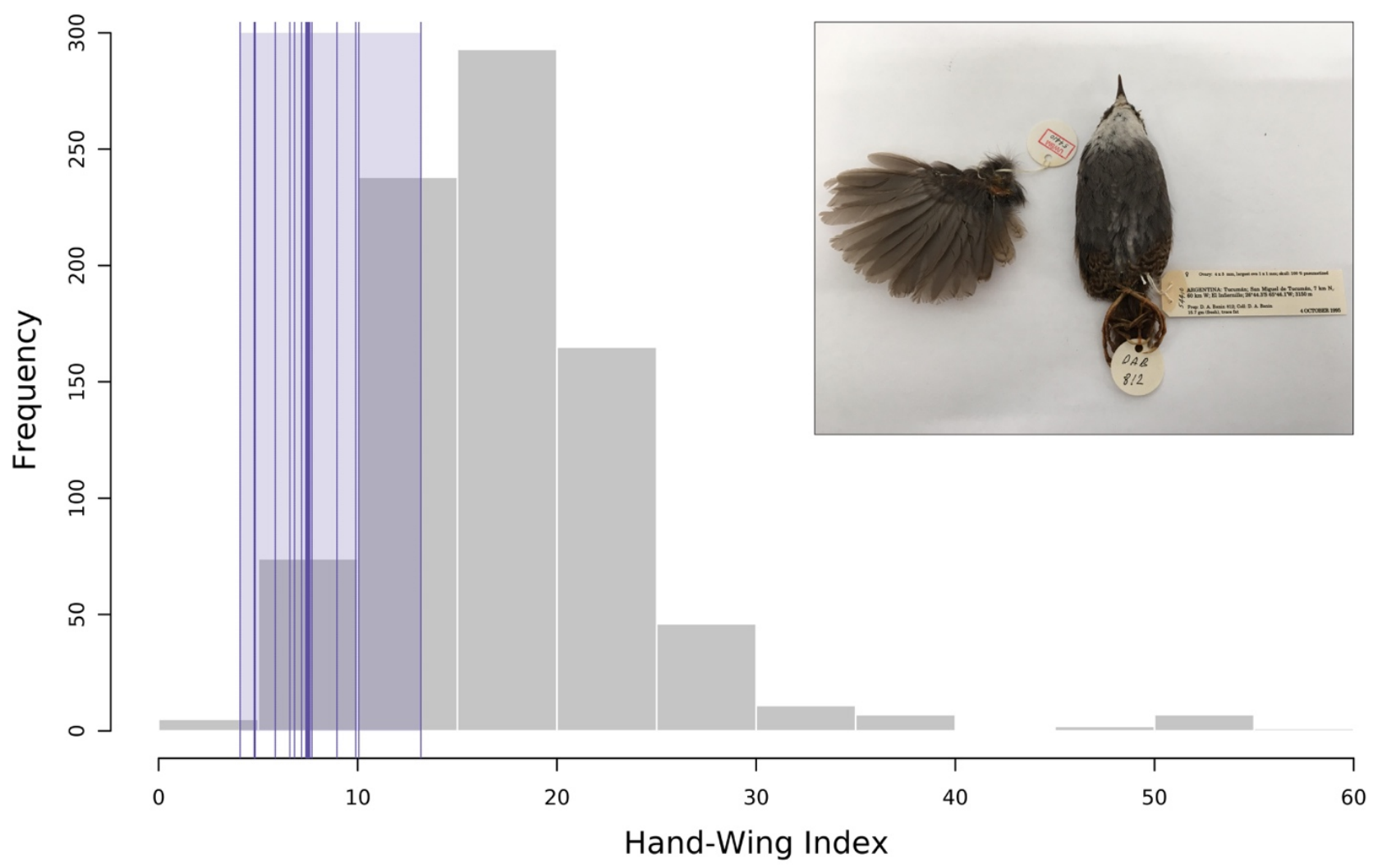

Figure 2. The frequency distribution of the hand-wing index, a proxy for dispersal abilities in birds, shows that Scytalopus tapaculos exhibit reduced potential for flighted dispersal relative to other birds. The dimensionless hand-wing index describes wing size and shape as a function of wing length (measured from the carpal joint to the longest primary feather) and secondary length (measured from the carpal joint to the tip of the first secondary feather), with larger values indicating greater dispersal abilities (Claramunt et al., 2012). The histogram in grey depicts the distribution of the hand-wing index across a sample of 851 species of New World passerine birds (measurements from Claramunt et al., 2012; P. Montoya, G. Bravo, and E. Tenorio, unpubl. data). Data for Scytalopus are in purple, showing the median (vertical thick bar) and the range (shaded area) of the hand-wing index across 12 species (thin bars are mean values per species). The inset illustrates the small and rounded wing of a specimen of S. superciliaris from Argentina housed at the Burke Museum of Natural History and Culture at the University of Washington (photograph by Cooper French). 
bioRxiv preprint doi: https://doi.org/10.1101/606558; this version posted May 6, 2019. The copyright holder for this preprint (which was not certified by peer review) is the author/funder, who has granted bioRxiv a license to display the preprint in perpetuity. It is made available under aCC-BY-NC 4.0 International license.
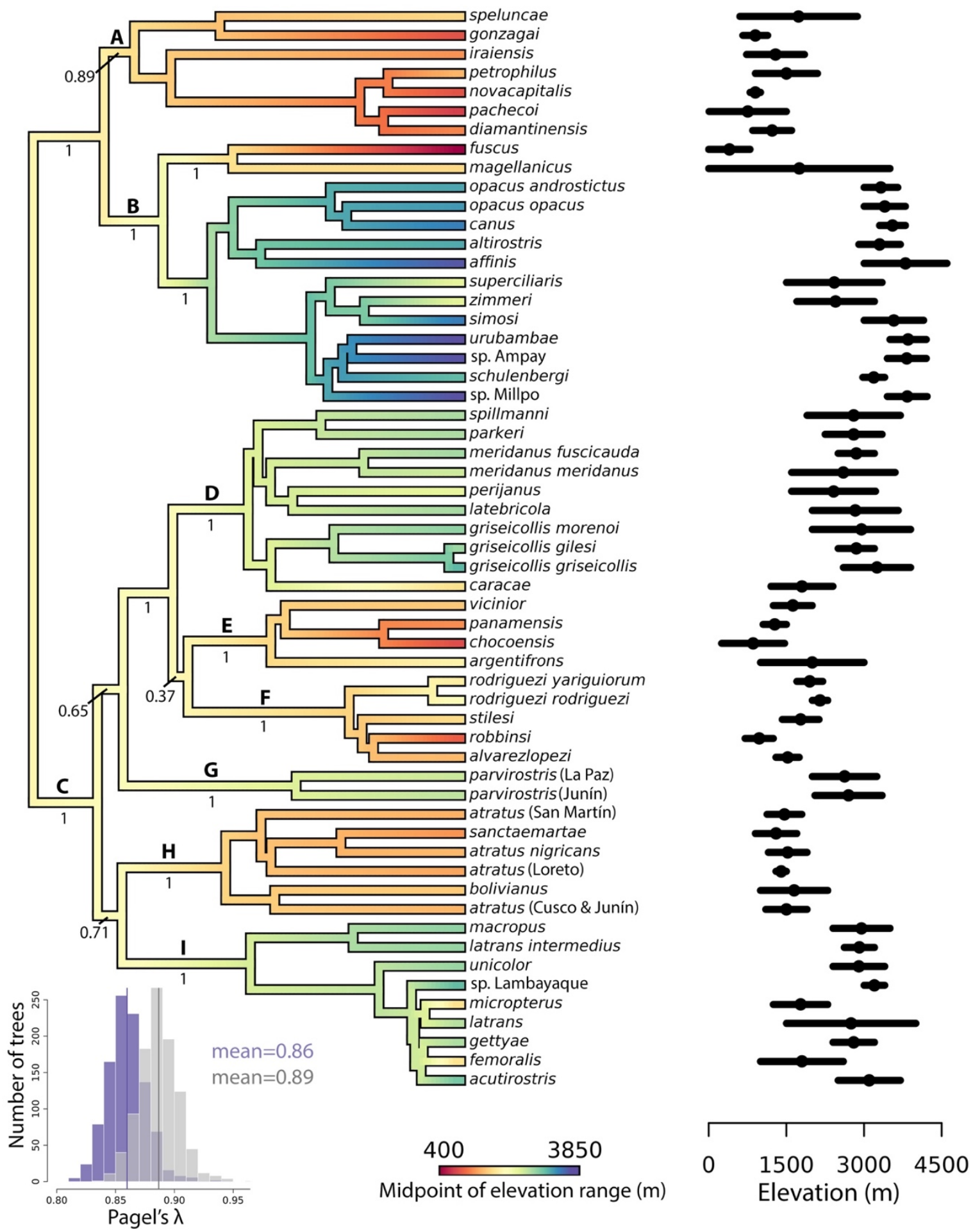

Figure 3. Elevational ranges of species are broadly similar within main clades of Scytalopus tapaculos and there is relatively high phylogenetic signal in midpoint of the elevational range. The phylogeny is the maximum clade credibility tree with midpoint of elevation mapped on branches using maximum-likelihood; posterior probabilities are shown only for major clades. The elevation range and midpoint elevation of each taxon are shown in front of each tip. The histogram in the bottom left depicts the distribution of phylogenetic signal in midpoint elevation measured by Pagel's $\lambda$ estimated across 1,001 posterior trees (purple for the 47-taxa data set, gray for the 57-taxa data set). 


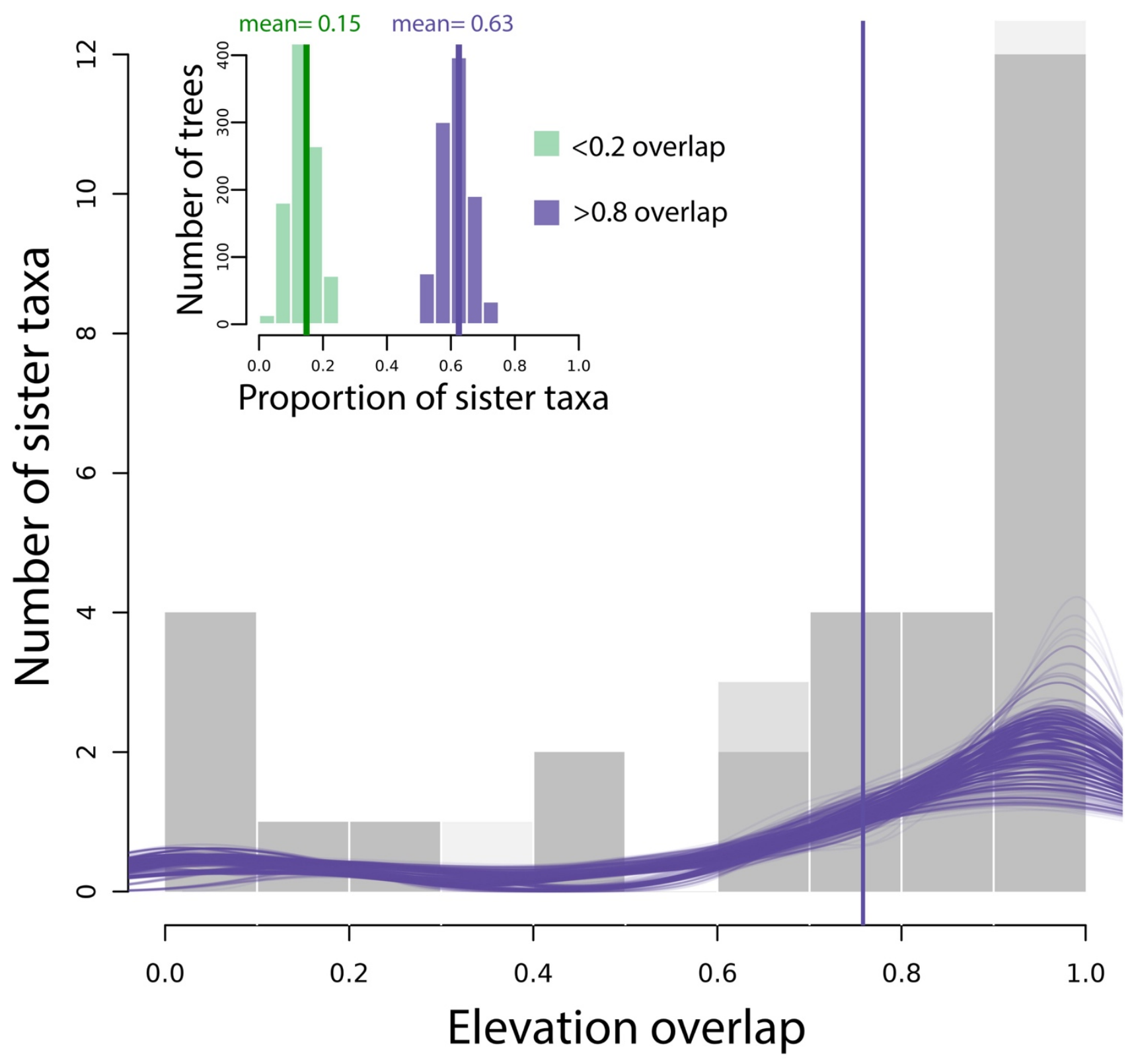

Figure 4. Most sister species of Scytalopus have similar elevational distributions. The main figure shows an overlay of 1,001 histograms, each corresponding to a phylogenetic tree in the posterior, showing the distribution of values of elevational overlap between sister taxa (0 indicates no overlap, 1 indicates complete overlap of elevational ranges); purple lines are density plots and the vertical line signals the pooled mean across trees. Histograms in the inset show the distribution of the proportion of sister taxa in the 57-taxon data set with little $(<0.2)$ and high overlap $(>0.8)$ in elevational distributions across the 1,001 trees. We obtained qualitatively similar results with the 47-taxon data set (see text). 

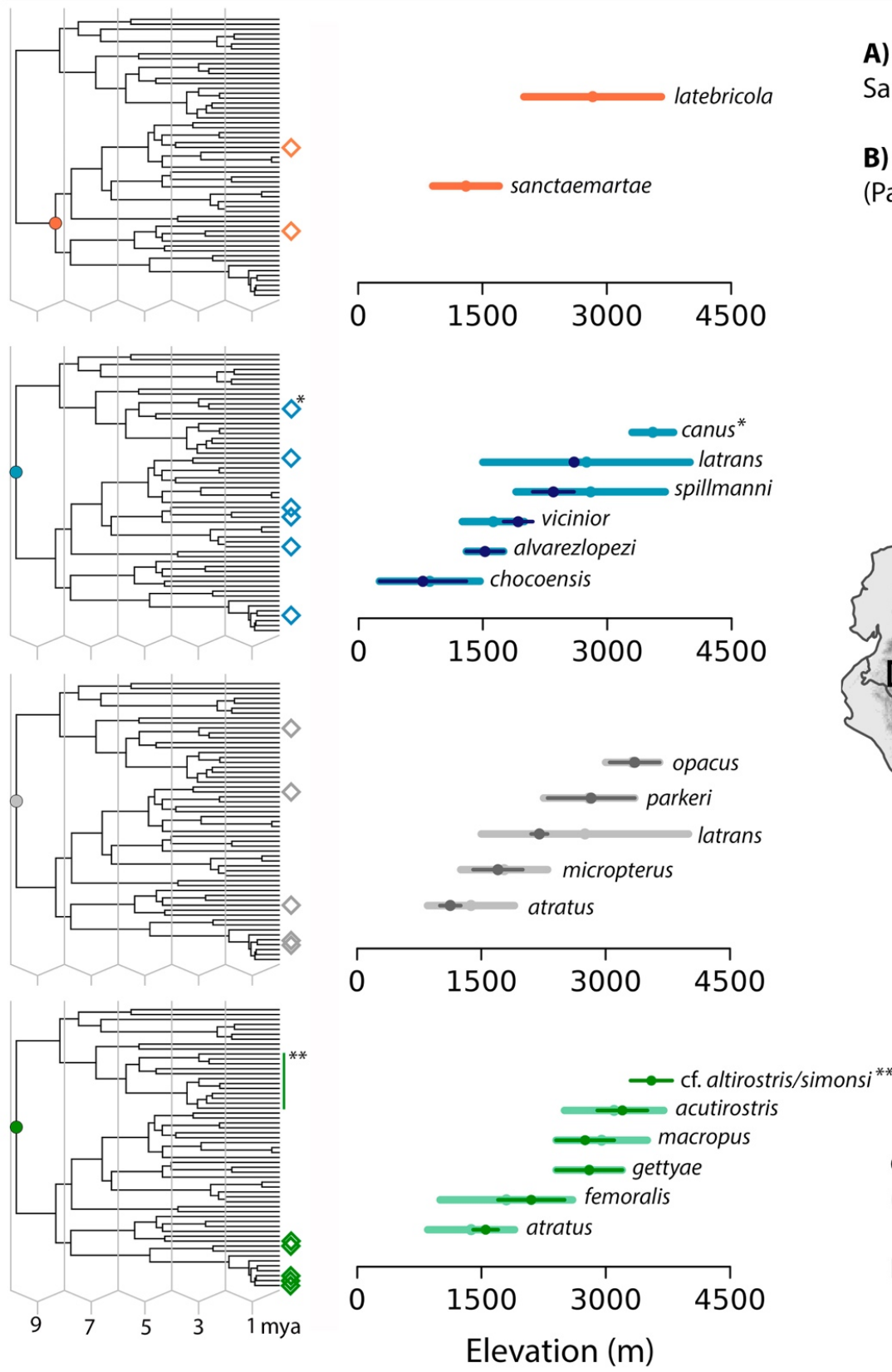

\section{A) Sierra Nevada de Santa Marta}

B) Cerro Montezuma (Pacific Slope)

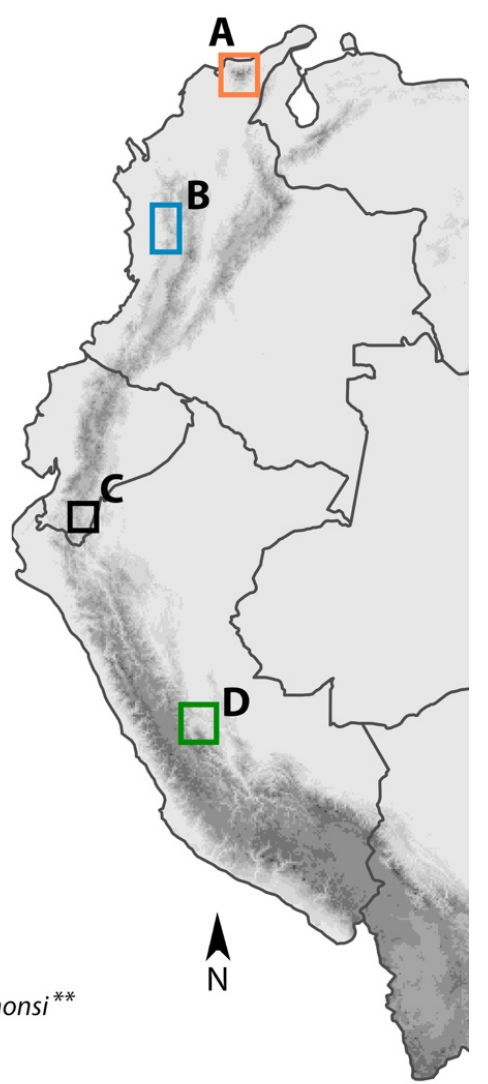

C) Zamora-Chinchipe (Amazonian slope)

\section{D) Río Satipo valley} (Amazonian slope)

Figure 5. Scytalopus species replacing each other with elevation in four regions of South America are often, but not always, distantly related. Rhombuses at the tips of the phylogeny highlight species that replace each other along each elevational gradient, and the dot denotes the most recent common ancestor of these species. Horizontal bars depict the elevational range of species, where the lighter color represents the elevation range for the species across its distribution and the darker color the elevational range reported for each specific gradient (B: Stiles et al., 2017; C: Krabbe \& Schulenberg, 1997; D: Hosner et al., 2013); a single bar is shown for the species from the Sierra Nevada de Santa Marta because both are endemic and for $S$. canus because the species does not occur in the specific gradient we highlight (i.e., Cerro Montezuma). The range of S. latrans in the Cerro de Montezuma is shown as a dot because it is only known from the very highest elevations in the area. Although the taxonomic identity of the species occurring at the highest elevations in the Satipo Valley gradient is uncertain, it very likely belongs to the clade depicted with the vertical line on the tree (Hosner et al., 2013). 
Table 1. Elevational distributions of Scytalopus tapaculos considered in analyses. For each taxon, we provide the minimum, maximum and midpoint of the elevation range (in $\mathrm{m}$ ), as well as sources for these data. Taxa with asterisks were those excluded from analyses involving only the 47 species recognized (or soon to be recognized) by taxonomists (see text).

\begin{tabular}{|c|c|c|c|c|}
\hline Taxa & Min. & Max. & Mid. & Source \\
\hline Scytalopus magellanicus & 0 & 3500 & 1750 & del Hoyo et al., 2018 \\
\hline Scytalopus altirostris & 2900 & 3700 & 3300 & Schulenberg et al., 2007 \\
\hline Scytalopus affinis & 3000 & 4600 & 3800 & Schulenberg et al., 2007 \\
\hline Scytalopus urubambae & 3500 & 4200 & 3850 & Schulenberg et al., 2007 \\
\hline Scytalopus simosi & 3000 & 4150 & 3575 & Herzog et al., 2016 \\
\hline Scytalopus zimmeri & 1700 & 3200 & 2450 & del Hoyo et al., 2018 \\
\hline Scytalopus superciliaris & 1500 & 3350 & 2425 & del Hoyo et al., 2018 \\
\hline Scytalopus fuscus & 0 & 800 & 400 & del Hoyo et al., 2018 \\
\hline Scytalopus canus & 3300 & 3800 & 3550 & A. Cuervo \\
\hline Scytalopus opacus opacus & 3000 & 3800 & 3400 & Ayerbe, 2018 \\
\hline Scytalopus opacus androstictus ${ }^{*}$ & 3000 & 3650 & 3325 & Krabbe \& Cadena, 2010 \\
\hline Scytalopus schulenbergi & 2975 & 3400 & 3187.5 & Whitney, 1994 \\
\hline Scytalopus sp. Ampay & 3450 & 4200 & 3825 & N. Krabbe \\
\hline Scytalopus sp. Millpo & 3450 & 4220 & 3835 & N. Krabbe \\
\hline Scytalopus speluncae & 600 & 2870 & 1735 & $\begin{array}{l}\text { del Hoyo et al., 2018/ V. } \\
\text { Piacentini }\end{array}$ \\
\hline Scytalopus gonzagai & 660 & 1140 & 900 & Maurício et al., 2014 \\
\hline Scytalopus petrophilus & 900 & 2100 & 1500 & Whitney et al., 2010 \\
\hline Scytalopus diamantinensis & 850 & 1600 & 1225 & Bornschein et al., 2007 \\
\hline Scytalopus pachecoi & 10 & 1500 & 755 & Maurício, 2005 \\
\hline Scytalopus iraiensis & 730 & 1850 & 1290 & Vasconcelos et al, 2008 \\
\hline Scytalopus novacapitalis & 800 & 1000 & 900 & del Hoyo et al., 2018 \\
\hline Scytalopus parvirostris (La Paz) & 2000 & 3250 & 2625 & N. Krabbe \\
\hline Scytalopus parvirostris (Junín)* & 2050 & 3350 & 2700 & N. Krabbe \\
\hline Scytalopus panamensis & 1050 & 1500 & 1275 & del Hoyo et al., 2018 \\
\hline Scytalopus chocoensis & 250 & 1465 & 857.5 & Krabbe \& Schulenberg, 1997 \\
\hline Scytalopus rodriguezi rodriguezi & 2000 & 2300 & 2150 & Krabbe et al., 2005 \\
\hline Scytalopus rodriguezi yariguiorum* & 1700 & 2200 & 1950 & Donegan et al, 2013 \\
\hline Scytalopus stilesi & 1420 & 2130 & 1775 & Cuervo et al., 2005 \\
\hline Scytalopus robbinsi & 700 & 1250 & 975 & Krabbe \& Schulenberg, 1997 \\
\hline Scytalopus vicinior & 1250 & 2000 & 1625 & Ridgely \& Greenfield, 2001 \\
\hline Scytalopus latebricola & 2000 & 3660 & 2830 & del Hoyo et al., 2018 \\
\hline Scytalopus meridanus meridanus & 1600 & 3600 & 2600 & Restall et al., 2006 \\
\hline Scytalopus meridanus fuscicauda* & 2500 & 3200 & 2850 & $\begin{array}{l}\text { Fjeldså \& Krabbe, 1990/ } \\
\text { Restall et al., } 2006\end{array}$ \\
\hline Scytalopus argentifrons & 1000 & 3000 & 2000 & del Hoyo et al., 2018 \\
\hline
\end{tabular}




\begin{tabular}{|c|c|c|c|c|}
\hline Scytalopus caracae & 1200 & 2400 & 1800 & del Hoyo et al., 2018 \\
\hline Scytalopus spillmanni & 1900 & 3700 & 2800 & del Hoyo et al., 2018 \\
\hline Scytalopus parkeri & 2250 & 3350 & 2800 & Krabbe \& Schulenberg, 1997 \\
\hline Scytalopus griseicollis griseicollis & 2600 & 3900 & 3250 & Krabbe \& Schulenberg, 1997 \\
\hline Scytalopus griseicollis gilesi* & 2500 & 3200 & 2850 & Donegan \& Avendaño, 2008 \\
\hline Scytalopus griseicollis morenoi* & 2000 & 3900 & 2950 & Avendaño \& Donegan, 2015 \\
\hline Scytalopus alvarezlopezi & 1300 & 1750 & 1525 & Stiles et al., 2017 \\
\hline Scytalopus perijanus & 1600 & 3225 & 2412.5 & Avendaño et al., 2015 \\
\hline Scytalopus sanctaemartae & 900 & 1700 & 1300 & del Hoyo et al., 2018 \\
\hline Scytalopus atratus nigricans (Tamá)* & 1150 & 1900 & 1525 & Hilty, 2003 \\
\hline Scytalopus atratus (Loreto) & 1300 & 1500 & 1400 & T. Schulenberg/ D. Lane \\
\hline Scytalopus atratus (SanMartín)* & 1125 & 1800 & 1462.5 & T. Schulenberg/ D. Lane \\
\hline Scytalopus atratus (Cusco \& Junín)* & 1100 & 1900 & 1500 & T. Schulenberg/ D. Lane \\
\hline Scytalopus bolivianus & 1000 & 2300 & 1650 & del Hoyo et al., 2018 \\
\hline Scytalopus latrans & 1500 & 4000 & 2750 & del Hoyo et al., 2018 \\
\hline Scytalopus latrans intermedius* & 2620 & 3200 & 2910 & N. Krabbe \\
\hline Scytalopus unicolor & 2400 & 3400 & 2900 & Schulenberg et al., 2007 \\
\hline Scytalopus macropus & 2400 & 3500 & 2950 & $\begin{array}{l}\text { Schulenberg et al., 2007/ } \\
\text { Fjeldså \& Krabbe, } 1990\end{array}$ \\
\hline Scytalopus micropterus & 1250 & 2300 & 1775 & del Hoyo et al., 2018 \\
\hline Scytalopus femoralis & 1000 & 2600 & 1800 & Schulenberg et al., 2007 \\
\hline Scytalopus acutirostris & 2500 & 3700 & 3100 & Schulenberg et al., 2007 \\
\hline Scytalopus gettyae & 2400 & 3200 & 2800 & Hosner et al, 2013 \\
\hline Scytalopus sp. Lambayeque & 3000 & 3400 & 3200 & D. Lane \\
\hline
\end{tabular}

